\title{
Problematyka praw dziecka oraz roli zabawy w procesie jego rozwoju i wychowaniu w świetle poglądów wybranych przedstawicieli myśli pedagogicznej $\mathrm{XX}$ wieku
}

\begin{abstract}
Reflection about the role of entertainment in children upbringing in the context of its rights in the pedagogical thought of twentieth

The twentieth century was special in the history of all mankind. Through many wars, a sense of security was disturbed, basic human needs were not satisfied. Paradoxically, it was at this age that particular attention was paid to children and their needs. This time became the century of the child through the recognition of his rights, which was particularly manifested in the appreciation of the role of play in upbringing.
\end{abstract}

Keywords: entertainment, upbringing, children's rights

\section{O zabawie - zamiast wstępu}

W książce pod tytułem Stulecie dziecka, wydanej w grudniu 1900 r., a zatytułowanej symbolicznie, autorka Ellen Key przedstawiła własne wyobrażenie wychowania, które byłoby potrzebne ludziom wieku dwudziestego. Motto z tego słynnego dzieła brzmiało: „Rodzicom, którzy wierzą, że w nowym stuleciu nowego człowieka stworzą”. Czy rzeczywiście jednak XX w. stworzył nowego człowieka? Był on czasem szczególnym w dziejach całej ludzkości: pierwsza i druga wojna światowa, wyścig zbrojeń, zimna wojna oraz rozwój i upadek państw komunistycznych - to wszystko odcisnęło ogromne piętno na ludziach na całym świecie. Łączyło się to z brakiem poszanowania życia i godności człowieka. Zostało zachwiane poczucie bezpieczeństwa, nie były zaspakajane podstawowe potrzeby ludzkie. Wojny siały ogromne spustoszenie - ginęli ludzie, niszczona była kultura i sztuka, zatracono wiarę w człowieczeństwo. Ludzie jednak na 
przekór temu wszystkiemu starali się żyć normalnie - zakładali rodziny, uczyli się, pracowali i bawili. I paradoksalnie to właśnie w tym wieku zwrócono szczególną uwagę na dzieci i ich potrzeby, jak również na główną ich działalność, czyli zabawę. Choć wagę zabawy w wychowaniu dostrzegali różni myśliciele na przestrzeni wieków, to jednak dopiero pod koniec XX w. powstała pedagogika zabawy, która mimo że nie jest dyscypliną naukową, a tylko symboliczną nazwą metodycznych poszukiwań ułatwiających pracę z grupą i proces uczenia, wykorzystuje dorobek wszystkich innych epok i całą gamę możliwości wynikających z zabawy. Proponuje ona działania dające członkom grupy możliwość rozwoju w atmosferze zaufania i wzajemnej akceptacji, bez względu na wiek i umiejętności. Wyzwala ona kreatywność i ciekawość, ułatwia nawiązywanie kontaktów z innymi oraz otaczającą rzeczywistością, po prostu wykorzystuje wszystko to, co zabawa ze sobą niesie ${ }^{1}$. Wiek XX rzeczywiście stał się stuleciem dziecka, a w wychowaniu zaczęto doceniać naturalne dążenie każdego dziecka do wymienionej wyżej działalności.

Mówiąc o dostrzeganiu roli zabawy na przestrzeni wieków przez różnych myślicieli, można przywołać kolejno takie nazwiska, jak: Platon (Prawa), Arystoteles (Polityka), Kwintylian (Kształcenie mówcy), John Locke (Myśli o wychowaniu), Jan Fryderyk Herbart (Wykłady pedagogiczne w zarysie), Fryderyk Froebel (Wychowanie człowieka, sztuka chowania, nauczania i uczenia się, do której się zmierza w powszechno-niemieckim zakładzie wychowawczym w Keilhau) i wielu innych. W utworach powyższych autorów można wyczytać, że zabawa dotyczy prawie każdej sfery życia dziecka i koniecznym jest podkreślenie jej roli w procesie uczenia się.

Jeszcze 50 lat temu pedagodzy obawiali się, że zabawa w nauczaniu szkolnym „zbytnio ułatwia i osładza wysiłki”, przez co „wpływa niekorzystnie na osobowość” oraz ,pochłania zbyt wiele czasu szkolnego, a równocześnie daje znacznie mniej konkretnych osiągnięć niż tradycyjne sposoby uczenia i że opóźnia przez to postęp klasy"2. $\mathrm{Z}$ czasem się to zmieniło i zabawa zaczęła być wykorzystywana również w dydaktyce, a następnie pod koniec XX w. również w pracy z osobami dorosłymi czy starszymi.

Istnieje kilka klasyfikacji rodzajów zabaw, jednak najpowszechniejszą wydaje się ta autorstwa Petra A. Rudika, który wyodrębnił ich cztery kategorie, a mianowicie konstrukcyjne, twórcze, dydaktyczne i ruchowe ${ }^{3}$. Podobną klasyfikację zastosowała Charlotte Bühler ${ }^{4}$, do której nawiązuje w swojej książce Stefan Szuman. Wymienia on za autorką trzy główne rodzaje zabaw: funkcjonalne, iluzyjne i konstrukcyjne. Pierwsze z nich kształcą funkcje sensoryczne i ruchowe dziecka, drugie wyobraźnię i fantazję,

${ }^{1}$ Encyklopedia pedagogiczna XXI wieku, red. T. Pilch, t. 4, Wydawnictwo Akademickie „Żak”, Warszawa 2005, s. 291-292.

2 A. Kamiński, Aktywizacja i uspołecznianie uczniów w szkole podstawowej, PZWS, Warszawa 1966, s. 29.

3 W. Okoń, Zabawa a rzeczywistość, Wydawnictwo „ŻAK”, Warszawa 1995, s. 159.

${ }^{4}$ Ch. Bühler, Dziecięctwo i mtodość. Geneza świadomości, Nasza Księgarnia, Warszawa 1933. 
a trzecie planowanie i ,antycypację wyobrażeniową" łalność to wrodzona, specjalna metoda uczenia się małego dziecka, swoista aktywność, dzięki której dziecko uczy się i zdobywa doświadczenie w wielu dziedzinach ${ }^{6}$. Wszelka działalność zabawowa ma duży wpływa na rozwój intelektualny, fizyczny, emocjonalny i społeczny.

Wraz z rozwojem dziecka zabawa zmienia swój charakter i funkcję, formy oraz

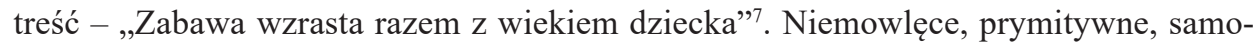
rzutne zabawy funkcjonalne i ruchowo-manipulacyjne (usprawniające ruchy rąk i motorykę ciała) przekształcają się w różnorodne zabawy, coraz bogatsze treściowo i organizacyjnie $^{8}$. Początkowo indywidualne, potem wspólne, zespołowe, są formą aktywności społecznej. Służą poznaniu nie tylko właściwości przedmiotów, ale również świata społecznego, a w nim ról społecznych (rodzinnych, zawodowych), wartości, tradycji i zwyczajów. Wprowadzają one dziecko w świat zjawisk społecznych, wdrażają do respektowania norm, do współdziałania, sprzyjają kształtowaniu się postaw moralnych oraz systemów wartości ${ }^{9}$. W tej sferze główną rolę odgrywają zabawy nazwane przez Rudika twórczymi.

Zabawy mają również duży wpływ na rozwój emocjonalny dziecka - pomagają mu przejść od emocjonalnego kontaktu z matką do autonomii emocjonalnej poprzez „przytulanki" bądź wyimaginowanych towarzyszy zabaw ${ }^{10}$. Ponadto dzieci podczas zabawy uczą się społecznie aprobowanego wyrażania własnych emocji oraz ich kontroli. Nabywają wiedzy o emocjach swoich i innych ludzi, jak odpowiednio na nie reagować oraz jak je nazywać ${ }^{11}$.

W rozwoju ruchowym zabawy również odgrywają istotną rolę. Wiążą się one z wykonywaniem ruchów, głównie lokomocyjnych, wymagających szybkości, zręczności i wysiłku, zaspokajają „głód ruchu”, zapewniają harmonijny rozwój fizyczny, uczą czynnego wypoczynku, a ponadto współdziałania i szlachetnej rywalizacji ${ }^{12}$. Oprócz zabaw ruchowych, biorąc pod uwagę klasyfikację Rudika, można tutaj wymienić również konstrukcyjne.

Ostatnią sferą, na rozwój której duży wpływ mają zabawy, to intelekt. Zabawy umysłowe (dydaktyczne) są sztucznie przygotowane przez dorosłych i nastawione na rozwijanie zdolności poznawczych, bo polegają na rozwiązywaniu zadań kończących się

\footnotetext{
${ }^{5}$ S. Szuman, Rozwój psychiczny dzieci i młodzieży, Instytut Wydawniczy „Nasza Księgarnia”, Warszawa

${ }^{6}$ Ibidem.

${ }^{7}$ W. Okoń, Zabawa, op. cit., s. 44.

${ }^{8}$ B. Harwas-Napierała, J. Trempała, Psychologia rozwoju człowieka, PWN, Warszawa 2003.

${ }^{9}$ Ibidem, s. 110-113.

10 Ibidem, s. 100.

11 Ibidem, s. 112-113.

12 Encyklopedia pedagogiczna, red. W. Pomykało, Fundacja Innowacja, Warszawa 1997, s. 933-934.
} 1948, s. 37-38. 
określonym wynikiem. Są one szeroko stosowane w przedszkolu i na początku szkoły podstawowej, a przybierają często postać materialnych środków dydaktycznych ${ }^{13}$. Nie tylko zabawy dydaktyczne, ale również twórcze i konstrukcyjne, przyczyniają się do rozwoju sfery intelektualnej u dzieci.

\section{Tendencje kultury europejskiej w zakresie poszerzania wiedzy o dziecku. Międzynarodowe organizacje i ich dokumenty dotyczące praw dziecka}

Przełom XIX i XX wieku to czas, w którym zaczyna się zauważać prawa dzieci. Powszechnie przytacza się przypadek 8-letniej Mary Elen Wilson z Baltimore, systematycznie bitej przez matkę. Dziewczynce pomocy udzielili członkowie lokalnego oddziału stowarzyszenia przeciwdziałania okrucieństwu wobec zwierząt ${ }^{14}$. Zdarzenie to zapoczątkowało w Stanach Zjednoczonych powstanie ruchu na rzecz pomocy dzieciom i wkrótce potem powołano ponad 200 różnych lokalnych stowarzyszeń mających na celu ochronę dzieci przed przemocą. Od 1880 r. zaczęły powstawać w Europie pierwsze towarzystwa międzynarodowe np. kryminologów, sędziów dla nieletnich, opieki nad dziećmi opuszczonymi i bezdomnymi, których działalność koncentrowała się na łagodzeniu przepisów prawa karnego wobec nieletnich, tworzeniu specjalnych instytucji wychowawczych i opiekuńczych dla dzieci itp. Na przykład w 1890 r. Kongres Kryminologów przyjął rezolucję ustalającą wiek 14 lat za granicę, poniżej której nie można stosować kar kryminalnych. W 1892 r. powstało Międzynarodowe Stowarzyszenie Opieki nad Dzieckiem (rząd polski przystąpił do stowarzyszenia w 1928 r., niestety nie powstał w Polsce jego oddział $)^{15}$.

Zbliżał się XX wiek. W Skandynawii pojawiły się plakaty o nadchodzącym stuleciu. Było na nich dziecko. Stąpało po Ziemi nieśmiało, z trudem znajdując dla siebie miejsce na globie najeżonym bagnetami, znaczonym ogniem wojen. Dziecko wielokrotnie symbolizowało lepszą przyszłość. Nie jest także przypadkiem, że radosny maluch z rózeczką uosabiał plakatowe nadzieje Solidarności ${ }^{16}$.

Były to jednak tylko płonne nadzieje, ponieważ XX w. nie przyniósł szczęścia dziecku i światu, chociaż wybawił od niewolniczej pracy, głodu i wielu innych zagrożeń

13 Ibidem, s. 934.

14 The Mission of Humanity. Continuation of the Proceedings Instituted by Mr. Bergh on Behalf of the Child, Mary Ellen Wilson (PDF). New York Times. April 11, 1874, https://timesmachine.nytimes.com/timesmachine/1874/04/11/79069541.pdf [dostęp 27.04.2019]; patrz także: https://www.unicef.pl/O-nas/Prawa-dziecka/ Geneza-praw-dziecka [dostęp: 27.04.2019]; http://www.tpdkrosno.pl/wp-content/uploads/2013/10/PrzyjacielDziecka-7-12_2011.pdf [dostęp: 27.04.2019].

15 E. Czyż, Prawa dziecka, Helsińska Fundacja Praw Człowieka, Warszawa 2002.

${ }^{16}$ B. Smolińska-Theiss, Dzieciństwo - obszary znane i nieznane, w: Prawa dziecka. Deklaracje i rzeczywistość, Materiały z Konferencji Rembertów 1921 czerwca 1992 r., red. J. Bińczycka, Oficyna Wydawnicza „Impuls”, Warszawa 1993, s. 95. 
związanych z wczesnym kapitalizmem. Świat nie był przyjazny dziecku, a i ono nie zmieniło świata - stało się narzędziem interesów politycznych umacniającym totalitaryzm, faszyzm, anarchizm, nacjonalizm i inne skrajnie niszczycielskie ruchy polityczne oraz dla umocnienia władzy partyjnej, do walki z rodziną, z kułactwem ${ }^{17}$.

Zeszły wiek uczył dzieci ofiarami przemocy dorosłych. Z obliczeń wynika, że w czasie II wojny światowej około 150 tysięcy dzieci zostało deportowanych do Rosji, 150 tysięcy żydowskich dzieci zginęło w getcie, wiele tysięcy trafiło do obozów koncentracyjnych, łagrów czy zakładów „wychowawczych” oraz stalinowskich obozów resocjalizacyjnych. Za czasów hitlerowskiego faszyzmu dzieci były narzędziem w rękach dorosłych, między innymi poprzez tworzenie systemu militarnego wychowania czy oddziałów Hitlerjugend. Również po wojnie zaczęły wychodzić na jaw przejawy gwałtu zadawanego dzieciom przez dorosłych: bicie, znęcanie się, wykorzystywanie seksualne, zmuszanie lub wyzyskiwanie do pracy. Również i później dzieci palestyńskie biorą udział w wojnie przeciw Żydom, a w byłej Jugosławii znane są fotografie, na których dzieci między dziesiątym a dwunastym rokiem życia uzbrojone są w pistolety maszynowe typu kałasznikow ${ }^{18}$.

Była to ciemna strona XX wieku i na tym gruncie coraz częściej stawiane były pytania o miejsce dziecka w świecie, szacunek do niego, jego prawa i możliwości ich respektowania. Jasną stroną było to, że właśnie wtedy dokonał się rozwój nauk biologicznych, medycznych i psychologicznych, które pozwoliły na poznanie organizmu dziecka, jego psychiki na każdym etapie rozwojowym.

Pierwsza wojna światowa uświadomiła ludziom, iż rozstrzyganie spornych spraw politycznych w wyniku działań zbrojnych niesie ze sobą straszliwe skutki. Naturalnym efektem po zakończonych działaniach wojennych stały się tendencje pacyfistyczne. Żeby zapobiec podobnym katastrofom oraz w sposób pokojowy zmienić świat, znów zaczęto myśleć o wychowaniu „nowego” człowieka, który będzie dobrze przygotowany do życia w pokoju i przeciwstawiał się wojnie ${ }^{19}$.

Te pacyfistyczne idee zmiany świata przez wychowanie nowego człowieka powodowały powstawanie międzynarodowych organizacji opieki nad dzieckiem, międzynarodowych stowarzyszeń wychowawczych itp., które uchwalały rozmaite apele i deklaracje, organizowały różnorodne kongresy i zjazdy pedagogiczne oraz podejmowały rozmaite akcje oświatowe i wychowawcze ${ }^{20}$.

Jedną z organizacji, która chciała pomagać w odrodzeniu ludzkości poprzez szerzenie reformy wychowania, była Międzynarodowa Liga Nowego Wychowania. Powstała

17 Ibidem, s. 95-96.

18 Ibidem, s. 96.

19 Ł. Kabzińska, Idea wychowania moralno-społecznego w programach międzynarodowych kongresów pedagogicznych okresu międzywojennego, „Warmińsko-Mazurski Kwartalnik Naukowy. Nauki Społeczne” 2013, nr 4 (8), s. 40.

${ }^{20}$ Ibidem, s. 522. 
ona na zjeździe pedagogicznym w Calais w 1921 r. i działała w trzech ośrodkach: w Londynie, Genewie i Berlinie. W statucie organizacji ogłoszono, że w celu realizacji „nowego wychowania” należy upowszechniać najlepsze metody dydaktyczne i wychowawcze, propagować reformy szkół w duchu „nowego wychowania” („na miarę sił dziecka dla pełni jego rozwoju biologicznego, kulturalnego i społecznego"), zakładać nowe szkoły, a to wszystko miało się odbywać dzięki współpracy nauczycieli i rodziców wszystkich krajów ${ }^{21}$.

Po I wojnie światowej powstał Międzynarodowy Związek Opieki nad Dzieckiem. Miał on za zadanie nieść pomoc przede wszystkim dzieciom, które w wyniku wojny zostały pozbawione opieki. Założycielką organizacji była Eglantine Jeb. Skierowała ona apel do ludzi całego świata: „Ratujcie dzieci pozbawione przez wojnę opieki!’. Dzięki niemu zaczęły powstawać komitety pomocy dzieciom cierpiącym nędzę, a w 1920 r. pod protektoratem Międzynarodowego Komitetu Czerwonego Krzyża w Genewie powstał Międzynarodowy Związek Opieki nad Dzieckiem. Podstawę działalności Związku stanowiła proklamowana 26 września 1924 r. Deklaracja Praw Dziecka (tzw. Deklaracja Genewska). W Deklaracji ogłoszono, że „ludzkość powinna dać dziecku to, co ma najlepszego", że dziecku należy się opieka bez względu na jego rasę, narodowość i wyznanie, że powinno się mu umożliwić normalny rozwój fizyczny, moralny i umysłowy, że dziecko głodne trzeba nakarmić, chore leczyć, upośledzonemu pomóc, nieprzystosowane do życia trzeba reedukować, sierotę i dziecko opuszczone trzeba przygarnąć i co najważniejsze - dziecko ma otrzymać pomoc w czasie szczególnego zagrożenia jako pierwsze ${ }^{22}$.

Zgromadzenie Ogólne Narodów Zjednoczonych 11 grudnia 1946 r. powołało do życia UNICEF (Fundusz Narodów Zjednoczonych Pomocy Dzieciom), organ pomocniczy ONZ. Początkowo miał udzielać pomocy dzieciom w krajach, które były ofiarami agresji w czasie II wojny światowej. Później rozszerzono zakres działań na sprawy zdrowia i wyżywienia oraz warunków życia dzieci głównie w krajach słabo rozwiniętych. UNICEF z czasem rozbudował swoją działalność po to, by zaspokoić interesy, potrzeby i prawa dziecka. Należy podkreślić to, że jednym z założycieli i pierwszym prezesem Rady Zarządzającej był Polak Ludwik Rajchman. Polska należy do organizacji od 1956 r. UNICEF współpracuje między innymi z UNESCO ${ }^{23}$.

W 1946 r. rozpoczęła działalność UNESCO (Organizacja Narodów Zjednoczonych do Spraw Oświaty, Nauki i Kultury) z siedzibą w Paryżu. Należy podkreślić, że w konferencji założycielskiej wzięła udział również Polska. Celem organizacji było m.in.

${ }^{21}$ Ibidem, s. 523-524.

22 A. Łopatka, Konwencja Praw Dziecka w Polsce, w: Prawa dziecka. Deklaracje i rzeczywistość. Materiaty z Konferencji Rembertów 19-21 czerwca 1992 r., red. J. Bińczycka, Oficyna Wydawnicza „Impuls”, Warszawa 1993, s. 16. S. 452 .

${ }^{23}$ Nowa encyklopedia powszechna PWN, red. B. Petrozolin-Skowrońska, t. II, PWN, Warszawa 1995, 
popieranie rozwoju szkolnictwa w krajach rozwijających się oraz walka $\mathrm{z}$ analfabetyzmem. W dziedzinie edukacji UNESCO kładzie nacisk głównie na te aspekty ${ }^{24}$.

Zgromadzenie Ogólne ONZ 10 grudnia 1948 r. uchwaliło Powszechną Deklarację Praw Człowieka, natomiast 20 listopada 1959 r. przy bardzo aktywnym udziale Polski proklamowało Deklarację Praw Dziecka, w której założono, że dziecko potrzebuje specjalnego zabezpieczenia i opieki, włączając w to odpowiednią ochronę prawną zarówno przed urodzeniem, jak i po nim. Deklaracja ma na celu zapewnienie szczęśliwego dzieciństwa i możliwości korzystania ze swoich praw dla dobra swojego i społeczeństwa. Dokument ma charakter uniwersalny, jego treść jest bogatsza i bardziej konkretna od Deklaracji Genewskiej z 1924 r. i przede wszystkim wiąże moralnie oraz politycznie wszystkich adresatów, w tym także rodziców ${ }^{25}$.

Ważny był również Międzynarodowy Pakt Praw Cywilnych i Politycznych jako pierwszy uniwersalny traktat międzynarodowy regulujący prawa dziecka i wiążący prawnie państwa, które do niego przystąpiły. Uchwalony został 16 grudnia 1966 r. Polska ratyfikowała go 17 marca $1977 \mathrm{r}$.

Tego samego dnia został uchwalony przez Zgromadzenie Ogólne ONZ Międzynarodowy Pakt Praw Ekonomicznych, Socjalnych i Kulturalnych. Zawiera on także postanowienia dotyczące bezpośrednio praw dziecka. Pakt ten także został ratyfikowany przez Polskę 18 marca 1977 r. $^{26}$.

Zgromadzenie Ogólne ONZ 21 grudnia 1976 r. proklamowało rok 1979 r. Międzynarodowym Rokiem Dziecka. Nasz kraj był jednym z inicjatorów tego przedsięwzięcia, którego celem było utworzenie ram dla działań na rzecz poprawy losu dzieci i zwrócenie uwagi opinii publicznej i decydentów na specjalne potrzeby dzieci, a programy dla dzieci krajowe i międzynarodowe, długo- i krótkoterminowe powinny być integralną częścią planów rozwoju ekonomicznego i socjalnego, pobudzające aktywność na rzecz poprawy losu dziecka. Rolę animatora obchodów Międzynarodowego Roku Dziecka pełnił UNICEF. ${ }^{27}$

Rząd polski, występując 7 lutego 1978 r. z projektem Konwencji Praw Dziecka, pragnął wykazać, że Polska - wbrew opiniom rozpowszechnionym w niektórych krajach - jest państwem szczerze i aktywnie zaangażowanym na rzecz promocji i ochrony praw człowieka. Prace nad uzgadnianiem projektu Konwencji w ramach ONZ trwały od 1978 r. do 20 listopada 1989 r., tj. do przyjęcia Konwencji przez Zgromadzenie Ogólne. Projekt przedłożony przez Polskę był kilkakrotnie modyfikowany, przez co w konsekwencji bardzo różni się od pierwotnego projektu. Jest znacznie bardziej wszechstronny, doskonalszy technicznie i bez porównania bardziej precyzyjny. Stanowi dzieło wszystkich państw oraz organizacji pozarządowych, które aktywnie

\footnotetext{
${ }^{24}$ Ibidem, t. IV, s. 671.

${ }^{25}$ A. Łopatka, Konwencja, op. cit., s. 17-18.

26 Ibidem, s. 18.

27 Ibidem, s. 18-19.
} 
uczestniczyły w jego wypracowaniu. Ostateczny tekst Konwencji wiele zawdzięcza UNICEF-owi, który od połowy lat osiemdziesiątych włączył się z wielkim nakładem energii i środków do prac nad Konwencją. Polska ma jednak szczególnie doniosły i konstruktywny wkład w powstanie tej Konwencji, która jest największym i jedynym tej rangi polskim wkładem $\mathrm{w}$ tworzeniu uniwersalnych standardów $\mathrm{w}$ dziedzinie praw człowieka $^{28}$.

W Polsce w 1981 r. powstał Komitet Ochrony Praw Dziecka (KOPD) ${ }^{29}$. W kręgu państw socjalistycznych była to inicjatywa niepowtarzalna - nigdzie do tamtej pory nie działało jakiekolwiek ciało społeczne, które publicznie twierdziłoby, iż niektóre z praw przysługujących dzieciom (zawartych m.in. w Deklaracji Praw Dziecka ONZ z 1959 r.) mogą być w tych krajach nierespektowane czy wręcz łamane. W październiku 1981 r. KOPD doczekał się rejestracji w Urzędzie Miasta Stołecznego Warszawy. Statut KOPD mówi, że jego głównym celem jest ochrona dziecka jako istoty nieświadomej przysługujących jej praw i niezdolnej do walki o ich przestrzeganie. Wprawdzie działalność KOPD w pewnej mierze powiela obszar, w którym powinny funkcjonować niektóre instytucje państwowe i inne organizacje społeczne, przykładowo: kuratorzy sądów rodzinnych i nieletnich, rodzinne ośrodki diagnostyczno-konsultacyjne, poradnie rodzinne, Towarzystwo Przyjaciół Dzieci, jednak w żadnej z tych instytucji nie ma pierwszeństwa sfera emocjonalnej dziecka, która dla KOPD jest najważniejsza ${ }^{30}$.

Dwudziestego listopada 1989 r. Zgromadzenie Ogólne Narodów Zjednoczonych uchwaliło jednomyślnie Konwencję Praw Dziecka. Konwencja weszła w życie 2 września 1990 r. Polska ratyfikowała ją 7 czerwca 1991 r. W stosunku do Polski weszła ona w życie miesiąc później, tj. 7 lipca 1991 r. Konwencja jest czymś w rodzaju światowej konstytucji praw dziecka, kamieniem milowym w historycznym procesie starań o poprawę jego losu ${ }^{31}$.

Jak wynika z powyższych rozważań, w XX w. stopniowo stwarzano warunki do tego, aby w pełni uregulować prawa dziecka jako człowieka. Stawało się ono podmiotem, a nie przedmiotem w rękach dorosłych. Wynikało to również z innych wydarzeń, które zmieniły to podejście. Rozwój nauk pozwolił na poznanie dziecka i praw jego rozwoju. Już na początku wieku wielu psychologów zajmowało się specyfiką psychiki dziecka i poczyniono w tym zakresie niezwykłe postępy. Jednym $\mathrm{z}$ aspektów, na które zaczęto zwracać uwagę, była zabawa - jako podstawowa czynność w dzieciństwie.

28 Ibidem, s. 19-21.

${ }^{29}$ M. Kątna, Komitet Ochrony Praw Dziecka wczoraj, dzisiaj, jutro, w: Prawa dziecka. Deklaracje i rzeczywistość. Materiały z Konferencji Rembertów 19-21 czerwca 1992 r., red. J. Bińczycka, Oficyna Wydawnicza „Impuls”, Warszawa 1993, s. 201.

30 Ibidem, s. 201-202; www.kopd.pl [dostęp 31.08.2016].

${ }^{31}$ A. Łopatka, Konwencja, op. cit., s. 15-16. 


\section{Doktryny pedagogiczne i ich wpływ na teorię i praktykę pedagogiczną wobec funkcji zabawy w rozwoju dziecka}

Ellen Key w swojej pracy po tytułem Stulecie Dziecka toruje na początku XX w. drogę kierunkowi ,pedagogiki do dziecka”. Opowiadała się ona głównie za swobodnym wychowaniem indywidualności dziecka. Świadczy o tym m.in. zacytowany poniżej fragment rozdziału jej dzieła zatytułowany Szkoła przyszłości:

Jednym z zadań przyszłości będzie wykształcenie nowego pokolenia matek, któreby wyzwoliły dzieci z systemu ogródków fröblowskich. Dzisiaj sądzimy, że kształcimy ludzi, gdy już dwu i trzyletnim dzieciom każemy żyć w gromadzie, w gromadzie występować, pracować według planu i gromadnie wykonywać wciąż te same bezsensowne robótki; w ten sposób mustrujemy tylko numery. Kto sam, dzieckiem będąc, bawił się na wybrzeżu morskim lub w lesie, w obszernym pokoju dziecinnym lub na strychu i widział inne dzieci, bawiące się $w$ ten sposób, ten wie, jak olbrzymią wartość posiada taka zabawa, jak pogłębia duszę, pobudza przedsiębiorczość i fantazję, jak zyskuje na porównaniu z zabawami i zajęciami rozpoczynanemi i przerywanemi na rozkaz starszych. Pod wpływem tych ostatnich dzieci przyzwyczajają się bawić się w gromadzie, zamiast w samoistności szukać zadowolenia - a przyzwyczajenie to jest cechą umysłów pospolitych. Skłaniamy dzieci do wytwarzania rzeczy niepotrzebnych i każemy nie myśleć, że pracują! Zadaniem wychowania powinno być właśnie nauczyć dzieci wstrętu do tych wszystkich bezpożytecznych rzeczy, które nasze dzisiejsze życie paczą i wynaturzają, nauczyć je, jak mają to życie uprościć, a poszukiwać tylko tego, co jego istotną wartość stanowi. System ogródków dziecięcych przeciwnie jest niezrównanym, jeśli chodzi o hodowanie słabych dyletantów i uległych członków gromady! ${ }^{12}$.

Autorka podkreśla, że to nie sama zabawa, a zabawa samodzielna dziecka, samoczynna i niekierowana przez dorosłych wbogaca jego duszę, rozwija przedsiębiorczość, pobudza fantazję. Zabawa kierowana przez dorosłych nie spełnia już tych funkcji. Każde działanie, a już w szczególności według jakiegoś z góry ustalonego planu, rozpoczynane i przerywane przez dorosłych, pozbawia dzieci „samoistności”. Ellen Key mocno krytykuje system ogródków freblowskich, ponieważ w nich dzieci już dwu- i trzyletnie żyją w dużej gromadzie, w której występują, pracują według planu i wykonują według niej bezsensowne roboty, co nie sprzyja rozwojowi, mówiąc współczesnym językiem, kreatywnego dziecka. Dlatego, czytamy dalej, jeśli nie można z nich zrezygnować, to chociaż sprawmy, żeby spełniały jeden podstawowy warunek - zabawa w nich musi być swobodna i niekierowana:

Jeśli w przyszłości niezbędnym się okaże ogródek dziecięcy, niechaj on będzie dla dzieci przybytkiem takiej swobody, jaką się cieszą małe szczenięta lub kociaki, niech się tam bawią własnym pomysłem, niech sobie same coś wynajdą, byleby im tylko dostarczono przedmiotów do prowadzenia swoich zabaw i towarzyszy do zabawy. Niechaj jaka rozsądna kobieta czuwa tam nad niemi i przygląda się im dla tego tylko, by czynnie wystąpić w chwili, gdy

${ }^{32}$ E. Key, Stulecie Dziecka, Księgarnia Naukowa, Krucza 44, Druk. K. Kowalewskiego, Mazowiecka 8, Warszawa 1904, s. 165. 
dziecko sobie samemu lub drugiemu krzywdę wyrządzić zamierza. Niech ona raz po raz pomoże im, opowie bajkę, lub nauczy je wesołej gry, lecz poza tym niech się zachowa biernie napozór, w rzeczywistości zaś niech niezmordowanie śledzi ich skłonności i rysy charakteru, wychodzące na jaw wśród zabawy. W tenże sam sposób powinnaby i matka śledzić zabawy dzieci, ich sposób postępowania z towarzyszami, ich skłonności, i zebrać jak najwięcej materjału, jak najmniej się wtrącając. Taka wytrwała, wszechstronna, pilna lecz bierna obserwacja w końcu doprowadzi matkę nieomal do zupełnie dokładnej znajomości dziecka33.

Chociaż autorka podkreśla wagę zabawy niekierowanej, to zastrzega jednak, że dziecka nie można zostawić całkowicie samemu sobie. Należy ciągle czuwać nad bezpieczeństwem zabawy, ale również dostarczyć na przykład niezbędnych do niej dziecku przedmiotów, które często dzieci same nie są w stanie zapewnić. Dorosły może również pokazać, jak można się bawić, przeczytać bajkę, nauczyć jakiejś gry, ale musi czynić w bardzo ostrożny sposób, tak żeby dziecko nie czuło się sterowane, tylko lekko nakierowane.

Ellen Key zwraca również na jeszcze jedną bardzo ważną funkcję zabawy - poprzez zabawę możemy poznać dziecko. We współczesnej pedagogice i psychologii stosuje się obserwację zabawy dziecka, aby je zdiagnozować. Choć Ellen Key nie mówi o diagnozie sensu stricto, podkreśla to, że taka obserwacja „wszechstronna, pilna, lecz bierna” może być kopalnią wiedzy o dziecku.

Pisząc dalej o szkole przyszłości, autorka znów zwraca uwagę na samodzielność dzieci podczas zabawy:

Prócz ogrodu będzie szkoła przyszłości miała wielką salę w gmachu szkolnym, a w ogrodzie boisko do gier i tańców, gdzie dzieci naprawdę swobodnie bawić się będą, t.j., nauczywszy się jakiej gry, pozostawione będą same sobie. Gry i zabawy, nieustannie kierowane przez nauczycieli, są tylko parodją zabawy ${ }^{34}$ !

Ostatnie zdanie jest kwintesencją poglądów autorki. Mimo upływu wieku jej postulaty są niezwykle aktualne i trafne.

Zgoła odmienny pogląd od Ellen Key głosił niemiecki pedagog, teoretyk „,szkoły pracy”, Georg Kerschensteiner. Mimo że zajmował się zagadnieniem pracy, nie omieszkał wspomnieć w swoim dziele również o zabawie. Traktuje ją jako jeden z etapów dorastania do pracy. Dzięki niej kształtują się w człowieku pewne cechy potrzebne do owocnej pracy. Autor pisze:

Praca zatem pedagogiczna ma wywierać wpływ zmierzający do tego, aby skierowana na cele działalność wychowanków powodowała w nich reakcję rzeczową, reakcję, której przedmiotem są wartości o walorze obiektywnym, a więc pozaczasowe. Do takich wartości należą: wartość prawdy, wartość moralności, wartość piękna, wartość zbawienia, krótko mówiąc, wartości

\footnotetext{
33 Ibidem, s. 165-166.

34 Ibidem, s. 183.
} 
zapewniające duszy ład wewnętrzny i jednolitość dla samego tylko ładu i jednolitości. Jest to tylko wtedy do osiągnięcia, gdy praca pozostawia po sobie taką właśnie postawę.

Jakimi drogami jednostka dochodzi do takiej postawy?

Wszelka działalność własna ma z początku charakter pędowy, samorzutny, ludyczny. Powoli, około drugiego roku życia, ustala się świadomość tego, że własne działanie powoduje skutki. Odtąd dziecko poczyna stopniowo dochodzić do rozróżniania w swoim działaniu skutku i przyczyny, a więc celu i środka. To rozróżnienie celu i środka jest pierwszym wielkim punktem zwrotnym w rozwoju psychicznym człowieka. Z dążenia dziecka do pozbawionej celu zabawy wyrasta teraz chęć do ujętej w prawidła gry z określonym celem lub do zajęć o wyraźnym celu, a w końcu wola do pracy z właściwym jej wysiłkiem i koniecznością przezwyciężania samego siebie ${ }^{35}$.

Dalej można znaleźć fragment, który opisuje inne funkcje zabawy:

A więc wszelką czynność uprawianą dla niej samej nazywamy zabawą. Z zabawy rozwijają się trzy inne formy czynności: sport, zajęcie, praca. Jakąś czynność nazywamy sportem, gdy celem czynności jest — na najwyższym stopniu stojąca - sprawność tej czynności. Dziecięca zabawa i sport nie mają żadnego celu, który by leżał poza samą czynnością. Inaczej ma się rzecz z zajęciem i pracą. Obydwa rodzaje czynności mają to do siebie, że je podejmujemy nie dla nich samych czy dla osiągnięcia najwyższej sprawności w tych czynnościach, lecz dla osiągnięcia ustanowionego przez wolę, ale obcego dla tej czynności celu ${ }^{36}$.

Georg Kerschensteiner zdaje się nie dostrzegać roli, jaką odgrywa zabawa w wychowaniu i rozwoju dziecka. Wielokrotnie pisze, że jest ona działalnością pozbawioną celu:

aktywność w pierwotnych zabawach dziecka, a przy tym nie tylko w grach ruchowych polegających na pełnym radości skakaniu, bieganiu, tańczeniu, lecz również w godzinami nieraz trwających zabawach iluzyjnych ze wszystkimi swymi wytworami - jest pozbawiona celu. Nie jest to nawet zabawa dla zabawy. Jest to po prostu wyładowywanie się popędu wewnętrznego ${ }^{37}$.

Stwierdzenie, że zabawa nie służy nawet zabawie, pomniejsza jej rolę. Autor zdaje się nie dostrzegać innych jej zalet, a za jedynie słuszną i rozwojową działalność uważa pracę. Dalej można znaleźć takie oto słowa: „Samorzutna zabawa dziecka jest typową formą zachowania się rzeczowego; nie dąży ona do żadnych celów ani poza sobą, ani w sobie; jest czynnością dla samej czynności"38.

Trudno jest się całkowicie zgodzić z jego tezami. Zabawa, owszem, pojawia się najpierw w rozwoju osobniczym człowieka i z pewnością dlatego jest traktowana jako coś bardziej prymitywnego. Jednak nie sposób nie docenić jej wpływu na rozwój człowieka.

35 J. Kerschensteiner, Pojęcie szkoły pracy. Podstawowy aksjomat procesu kształcenia, tłum. i oprac. B. Nawroczyński, Zakład Narodowy im. Ossolińskich Wydawnictwo Polskiej Akademii Nauk, Wrocław-Warszawa-Kraków 1970, s. 45-46.

36 Ibidem, s. 48.

37 Ibidem, s. 129.

38 Ibidem, s. 193. 
Jednym słowem, stanowi ona podwaliny do wychowania i kształcenia dziecka $\mathrm{i}$ jest odrębną jakościowo działalnością ludzką, a nie tylko, jakby chciał tego autor, etapem i drogą prowadzącą do jednego słusznego celu - pracy.

\section{Zakończenie}

Wraz z upływem czasu zmienia się świat, a z nim ludzie i ich potrzeby. Choć w powyższej pracy nie ma opisu stanowisk dotyczących znaczenia zabawy w poprzednich wiekach, ukazano podejście do niej w XX wieku - w czasie, w którym została w końcu doceniona i zaczęto ją poważnie traktować. Poprzednie stulecie obfitowało w zdarzenia antyhumanitarne (liczne wojny czy zbrodnie przeciwko ludzkości), a jednak mimo to, a może właśnie dlatego, znaleziono czas na rozważania zupełnie przeciwstawne. Przed XX w. nie dostrzegano wystarczająco jej wagi, następnie zaczęto ją doceniać w zeszłym stuleciu. Obecnie, mimo że każdy rozumie potrzebę wykorzystania jej w działalności wychowawczej i edukacyjnej i nikt nie podważa jej zalet, paradoksalnie odchodzi się od niej na rzecz zamykania się w pokoju przed telewizorem czy komputerem. Oczywiście znajdą się głosy, że i to jest potrzebne - trudno zaprzeczyć. Jednak to tylko jeden z jej wymiarów. O innych piszą kolejni autorzy, zarówno z dziedziny psychologii, socjologii, jak i pedagogiki. Obecnie świat jest nastawiony na zysk, korzyść, produktywność efekty. To dlatego coraz młodsze dzieci prócz do przedszkola czy szkoły posyłane są na ciągle zwiększającą się liczbę zajęć pozalekcyjnych - tańce, tenis, jazdę konną, języki obce (których uczą się, zanim jeszcze opanują mowę ojczystą) czy inne „pożyteczne” aktywności. A zabawę traktuję się jako stratę czasu, bo jest „nieproduktywna”, do niczego nie prowadzi. Artykuł ma ukazać, jak bardzo niebezpieczne jest takie myślenie - zabawa jest przecież potrzebna do prawidłowego wszechstronnego rozwoju, o czym piszą różni autorzy. Korzystnie wpływa na intelekt, osobowość oraz ciało. Nieskrępowana służy rozwojowi kreatywności, elastyczności i szybkości dostosowywania się do zmieniającego się otoczenia. Ponadto rozwija takie umiejętności, jak planowanie, kontrolowanie emocji oraz uczy zachowania społecznego. Są to tylko niektóre pozytywne jej strony, najbardziej spełniające oczekiwania współczesnego świata. Trzeba również zmienić myślenie, ponieważ zabawa nie jest przeciwieństwem pracy, tylko smutku i depresji, które również poprzez zabawę można diagnozować u dzieci i leczyć, na przykład za pomocą bajkoterapii czy niedyrektywnej terapii zabawowej. Artykuł - z racji swej ograniczonej formy - ukazuje tylko niewielką część dokonań w tym zakresie w „stuleciu dziecka”. Poniżej tylko wspomnę o osobach, które zajmowały się poruszaną w tekście tematyką.

Wśród europejskich psychologów zajmujących się zagadnieniem zabawy można wymienić takie nazwiska, jak Jean Piaget ${ }^{39}$, Daniel Borysowicz Elkonin ${ }^{40}$ czy Édouard

\footnotetext{
39 J. Piaget, B. Inhelder, Psychologia dziecka, Wydawnictwo Siedmioróg, Wrocław 1999.

${ }^{40}$ D.B Elkonin., Psychologia zabawy, WSiP, Warszawa 1984,.
} 
Claparède ${ }^{41}$, a z polskich należy wspomnieć o Stefanie Baleyu ${ }^{42}$, Stefanie Szumanie ${ }^{43}$, Marii Przetacznikowej ${ }^{44}$, Władysławie Janie Dynerze ${ }^{45}$ i Halinie Spionek ${ }^{46}$. Badali oni wpływ zabawy na rozwój psychiki dziecka, ogólne funkcje umysłowe i procesy poznawcze, takie jak: spostrzeganie, myślenie, wyobraźnię twórczą czy ciekawość. Podkreślali połączenie zabawy z życiem społecznym, jej wpływ na rozwój sfery moralnej dzięki uczeniu się w zabawie norm stosunków między ludźmi, a także rozwój motywacji oraz samodzielności, ale o jej społecznym znaczeniu szerzej traktują socjolodzy.

Z socjologicznego punktu widzenia o zabawie pisali Johan Huizinga ${ }^{47}$, Roger Caillois $^{48}$ czy Bogdan Sułkowski ${ }^{49}$. Ukazywali oni jej wpływ na zdobywanie umiejętności potrzebnych w życiu społecznym, w szczególności wzorów kulturowych. Zabawa jest aktywnością służącą rozrywce, sięgającą najgłębszych początków ludzkości. Z antropologicznego punktu widzenia nie istnieje społeczność (kultura, cywilizacja), której członkowie nie znaliby zabawy. Dzięki niej również odbywa się socjalizacja dziecka, uczy się ono norm i reguł życia w społeczeństwie. Odgrywa różne role społeczne, przez co poznaje je i uczy się ich. Nabywa umiejętności współpracy w grupie.

Refleksja o roli zabawy w wychowaniu umysłowym dzieci w myśli pedagogicznej XX wieku kształtowała się dzięki pracom takich osób, jak Maria Weryho-Radziwiłło-

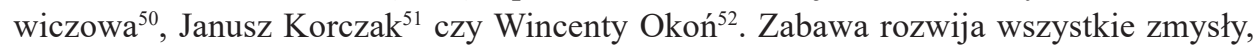
zmusza dziecko do jej urozmaicenia, przez co uczy pomysłowości. Dziecko kształci w nich swoją wyobraźnię, nabywa umiejętności szybkiego reagowania. Zabawa, dając

${ }^{41}$ É. Claparède, Psychologja dziecka i Pedagogika eksperymentalna, thum. M. Górska, Bibljoteka Dzieł Pedagogicznych, Warszawa 1927.

${ }^{42}$ S. Baley, Zarys psychologji w związku z rozwojem psychiki dziecka, Książnica - Atlas, Lwów 1935. 1948.

43 S. Szuman, Rozwój psychiczny dzieci i młodzieży, Instytut Wydawniczy „Nasza Księgarnia”, Warszawa

${ }_{44}$ M. Przetacznik-Gierowska, G. Makieło-Jarża, Psychologia rozwojowa i wychowawcza wieku dziecięcego, WSiP, Warszawa 1985.

${ }^{45}$ W.J. Dyner, Zabawy tematyczne dzieci $w$ domu $i$ w przedszkolu, Zakład Narodowy im. Ossolińskich, Wrocław 1971.

${ }^{46}$ H. Spionek, Rozwój i wychowanie małego dziecka, „Nasza Księgarnia”, Warszawa 1963,

${ }^{47}$ J. Huizinga, Homo ludens. Zabawa jako źródto kultury, tłum M. Kurecka, W. Wirpsza, Czytelnik, Warszawa 1985. 1997.

${ }^{48}$ R. Caillois, Gry i ludzie, tłum. A. Tatarkiewicz, M. Żurowska, Oficyna Wydawnicza Volumen, Warszawa

49 B. Sułkowski, Zabawa. Studium socjologiczne, PWN, Warszawa 1984.

${ }_{50}$ M. Weryho-Radziwiłłowiczowa, Metoda wychowania przedszkolnego, Podręcznik dla wychowawców, Książnica - Atlas, Zjednocz. Zakłady Kartograficzne i Wydawnicze Tow. Naucz. Szkół Średni. i Wyższ., SA., Lwów-Warszawa 1931.

51 J. Korczak, Pisma wybrane, t. I, ,, Wielka synteza dziecka - oto co mi się śniło”, wprow. i wybór A. Lewin, Nasza Księgarnia, Warszawa 1978.

52 W. Okoń, Zabawa a rzeczywistość, Wydawnictwo „ŻAK”, Warszawa 1995. 
dziecku uczucie zadowolenia, pobudza je do twórczości oraz prowadzi dziecko do samopoznania poprzez wypróbowanie swoich sił oraz poznanie wartości poprzez mierzenie się i porównywanie z innymi dziećmi. W zabawie dzieci kształcą mówienie, czytanie, pisanie, liczenie czy rysowanie oraz inne umiejętności, np. budowanie, lepienie czy majsterkowanie, dzięki czemu zdobywają wiadomości o różnorodnych materiałach, ich własnościach, o narzędziach pracy i sposobach posługiwania się nimi, poznają nazwy materiałów i narzędzi, uczą się zasad i sposobów konstrukcji, opanowują sprawności techniczne potrzebne w życiu. Dzięki zabawie dokonuje się również kształcenie zmysłów: wzroku, słuchu, dotyku, smaku, węchu, równowagi, temperatury, kinestetycznego, kształcenie wyższych zdolności poznawczych: pamięci, uwagi, zmysłu obserwacji, wyobraźni, myślenia oraz rozwój mowy.

W myśli pedagogicznej XX w. u tych samych autorów kształtowała się również refleksja o roli zabawy w wychowaniu fizycznym dzieci. W zabawie kształci się nie tylko siły fizyczne, ale również zręczność, dokładność i lekkość ruchów. Aktywność ta prowadzi do harmonijnego rozwoju ciała dziecka, a szczególnych walorów nabiera podczas uprawiania jej na świeżym powietrzu. Prowadzi do wszechstronnego opanowania ruchów własnego ciała, poznania ruchów i własności innych ciał oraz zharmonizowanie ruchów własnego ciała $\mathrm{z}$ ruchami innych ciał.

Natomiast jeśli chodzi o wpływ zabawy na rozwój społeczno-moralny dzieci, to również w poglądach Marii Waryho-Radziwiłłowiczowej, Janusza Korczaka czy Wincentego Okonia można znaleźć słowa, które świadczą o tym, że dzięki niej również dzieci nabierają śmiałości i pewności siebie, ćwiczą wolę, uczucia i charakter. Dzięki regułom obowiązującym w zabawach dziecko walczy również ze swoimi słabościami, takimi jak nieśmiałość, zawziętość czy niecierpliwość. Zabawa wpływa także na kształtowanie się pozytywnych postaw związanych z podporządkowaniem się, rywalizacją i współdziałaniem.

Założeniem tego tekstu było przybliżenie zagadnienia zabawy jako niezbywalnej i integralnej części rodzących się w XX w. praw dziecka. Aktywność ta została gruntownie zbadana oraz opisana przez pedagogów, psychologów i socjologów w kontekście wychowania oraz nauczania czy uczenia się. Interdyscyplinarne ujęcie zabawy ukazuje jej przemożny wpływ na wiele sfer w życiu człowieka, a nowoczesne ukazanie tego zagadnienia zmusza do rozważania zabawy jako aktywności pożytecznej nie tylko w wieku dziecięcym, ale w dorosłości czy nawet późnej starości. Należy pamiętać, że pedagogika jest dziedziną interdyscyplinarną, dlatego wszelkie rozważania nawiązujące do socjologii czy psychologii są jak najbardziej na miejscu. Poprzez zabawę realizuje się prawo dziecka do szczęśliwego dzieciństwa. 


\section{Bibliografia}

Opracowania

Baley S., Zarys psychologji w związu z rozwojem psychiki dziecka, Lwów 1935.

Bühler Ch., Dziecięctwo i młodość. Geneza świadomości, Warszawa 1933.

Caillois R., Gry i ludzie, tłum. A. Tatarkiewicz, M. Żurowska, Warszawa 1997.

Claparède É., Psychologja dziecka i Pedagogika eksperymentalna, tłum. M. Górska, Warszawa 1927.

Czyż E., Prawa dziecka, Warszawa 2002.

Dyner W. J., Zabawy tematyczne dzieci w domu i w przedszkolu, Wrocław 1971.

Elkonin D. B., Psychologia zabawy, Warszawa 1984.

Encyklopedia pedagogiczna, red. W. Pomykało, Warszawa 1997.

Encyklopedia pedagogiczna XXI wieku, red. T. Pilch, t. IV, Warszawa 2005.

Harwas-Napierała B., Trempała J., Psychologia rozwoju człowieka, Warszawa 2003.

Huizinga J., Homo ludens. Zabawa jako źródło kultury, tłum. M. Kurecka, W. Wirpsza, Warszawa 1985.

Kabzińska Ł., Idea wychowania moralno-spolecznego w programach międzynarodowych kongresów pedagogicznych okresu międzywojennego, „Warmińsko-Mazurski Kwartalnik Naukowy. Nauki Społeczne" 2013, nr 4 (8), 39-66.

Kamiński A., Aktywizacja i uspołecznianie uczniów w szkole podstawowej, Warszawa 1966.

Kątna M., Komitet Ochrony Praw Dziecka wczoraj, dzisiaj, jutro, w: Prawa dziecka. Deklaracje i rzeczywistość. Materiały z Konferencji Rembertów 19-21 czerwca 1992 r., red. J. Bińczycka, Warszawa 1993.

Kerschensteiner J., Pojęcie szkoły pracy. Podstawowy aksjomat procesu kształcenia, Wstęp, przekład i opracowanie Bogdana Nawroczyńskiego, Wrocław-Warszawa-Kraków 1970.

Key E., Stulecie Dziecka, Księgarnia Naukowa, Krucza 44, Druk. K. Kowalewskiego, Mazowiecka 8, Warszawa 1904.

Komitet Ochrony Praw Dziecka, www.kopd.pl [dostęp 21.08.2016].

Korczak J., Pisma wybrane, Tom I „Wielka synteza dziecka - oto co mi się śnito”, wprow. i wybór A. Lewin, Warszawa 1978.

Łopatka A., Konwencja Praw Dziecka w Polsce, w: Prawa dziecka. Deklaracje i rzeczywistość”, Materiały z Konferencji Rembertów 19-21 czerwca 1992 r., red. J. Bińczycka, Warszawa 1993.

Nowa encyklopedia powszechna PWN, red. B. Petrozolin-Skowrońska, t. II, Warszawa 1995.

Okoń W., Zabawa a rzeczywistość, Warszawa 1995.

Piaget J., Inhelder B., Psychologia dziecka, Wrocław 1999.

Prawa dziecka. Poradnik nauczyciela, red. K. Koszewska, Warszawa 2002.

Przetacznik-Gierowska M., Makieło-Jarża G., Psychologia rozwojowa i wychowawcza wieku dziecięcego, Warszawa 1985.

Smolińska-Theiss B., Dzieciństwo - obszary znane i nieznane, w: Prawa dziecka. Deklaracje i rzeczywistość. Materiaty z Konferencji Rembertów 19-21 czerwca 1992 r., red. J. Bińczycka, Warszawa 1993.

Spionek H., Rozwój i wychowanie małego dziecka, Warszawa 1963.

Sułkowski B., Zabawa. Studium socjologiczne, Warszawa 1984.

Szuman S., Rozwój psychiczny dzieci i młodzieży, Warszawa 1948.

Weryho-Radziwiłłowiczowa M., Metoda wychowania przedszkolnego. Podręcznik dla wychowawców, Lwów-Warszawa 1931. 


\section{Źródła internetowe}

„Przyjaciel Dziecka” - czasopismo Towarzystwa Przyjaciół Dzieci, http://www.tpdkrosno.pl/wpcontent/uploads/2013/10/Przyjaciel-Dziecka-7-12_2011.pdf [dostęp: 27.04.2019]

The mission of humanity. Continuation of the proceedings instituted by Mr. Bergh on behalf of the child, Mary Ellen Wilson (PDF). New York Times. April 11, 1874, https://timesmachine.nytimes.com/timesmachine/1874/04/11/79069541.pdf [dostęp: 27.04.2019].

UNICEF, https://www.unicef.pl/O-nas/Prawa-dziecka/Geneza-praw-dziecka [dostęp: 27.04.2019]. 